\title{
Perinatal neuroprotection
}

\section{Kirsten E. Salmeen ${ }^{1}{ }^{*}$, Angie C. Jelin ${ }^{2}$ and Mari-Paule Thiet $^{3}$}

Addresses: ${ }^{1} 513$ Parnassus Avenue, Room HSE-1634, Box 0556, San Francisco, CA 94143-0556, USA; ${ }^{2} 106$ Irving Street, NW, Room POB 108 , Washington, DC 20010, USA; ${ }^{3} 505$ Parnassus Avenue, Moffitt 1478, Box 0132, San Francisco, CA 94143-0132, USA

*Corresponding author: Kirsten E. Salmeen (salmeenk@obgyn.ucsf.edu)

FI000Prime Reports 2014, 6:6 (doi:10.12703/P6-6)

This is an open-access article distributed under the terms of the Creative Commons Attribution-Non Commercial License (http://creativecommons.org/licenses/by-nc/3.0/legalcode), which permits unrestricted use, distribution, and reproduction in any medium, provided the original work is properly cited. You may not use this work for commercial purposes.

The electronic version of this article is the complete one and can be found at: http://fl 000.com/prime/reports/m/6/6

\begin{abstract}
Fetal or neonatal brain injury can result in lifelong neurologic disability. The most significant risk factor for perinatal brain injury is prematurity; however, in absolute numbers, full-term infants represent the majority of affected children. Research on strategies to prevent or mitigate the impact of perinatal brain injury ("perinatal neuroprotection") has established the mitigating roles of magnesium sulfate administration for preterm infants and therapeutic hypothermia for term infants with suspected perinatal brain injury. Banked umbilical cord blood, erythropoietin, and a number of other agents that may improve neuronal repair show promise for improving outcomes following perinatal brain injury in animal models. Other preventative strategies include delayed umbilical cord clamping in preterm infants and progesterone in women with prior preterm birth or short cervix and avoidance of infections. Despite these advances, we have not successfully decreased the rate of preterm birth, nor are we able to predict term infants at risk of hypoxic brain injury in order to intervene prior to the hypoxic event. Further, we lack the ability to modulate the sequelae of neuronal cell insults or the ability to repair brain injury after it has been sustained. As a consequence, despite exciting advances in the field of perinatal neuroprotection, perinatal brain injury still impacts thousands of newborns each year with significant long-term morbidity and mortality.
\end{abstract}

\section{Introduction}

Perinatal brain injury can cause lifelong motor, sensory, and cognitive dysfunction. Injury may occur as a result of hypoxia, thrombosis, hemorrhage, infection, or trauma. All neonates are at risk; however, prematurity is the most significant risk factor for neurologic injury. The long-term impact depends on gestational age and duration and severity of the event. This review summarizes the pathophysiology, current clinical recommendations, and latest research on strategies to mitigate the impact of or prevent perinatal brain injury ("perinatal neuroprotection").

Research on perinatal neuroprotection typically focuses on the incidence of cerebral palsy (CP). CP is defined as "a group of permanent disorders of the development of movement and posture, causing activity limitation, that are attributed to non-progressive disturbances that occurred in the developing fetal or infant brain...often accompanied by disturbances of sensation, perception, cognition, communication and behavior" [1]. The overall incidence of CP in the United States is approximately 2 per 1,000 infant survivors with an incidence of 60 per 1,000 among infants weighing less than 1,500 grams [2]. In 2003, the Centers for Disease Control and Prevention estimated overall lifetime costs of CP for a child born in the United States to be $\$ 920,000$ [3]. Extrapolated to 2013 dollars, the cost is greater than $\$ 1.1$ million. In Denmark in 2009, the lifetime cost of CP was similarly estimated to be approximately $€ 830,000$ ( $\$ 1.1$ million) or $\$ 1.2$ million extrapolated to 2013 dollars [4]. It is important to note that a significant number of children who have cognitive abnormalities attributable to perinatal brain injury, but who do not meet criteria for CP, may be excluded from studies of perinatal neuroprotection due to challenges of diagnosis. 
Researchers have attempted to identify strategies for perinatal neuroprotection for decades. Historically, antenatal corticosteroids were the only available intervention for preterm infants, decreasing the risk of intraventricular hemorrhage (IVH), which is highly associated with $\mathrm{CP}$, by up to $65 \%$ [5]. Several recent advances, including magnesium sulfate and therapeutic hypothermia, show promise at reducing the long-term consequences of brain injury. Additionally, preventative strategies, including delayed cord clamping, progesterone to prevent recurrent preterm birth, and avoidance of infections, may reduce the incidence of perinatal brain injury. Unfortunately, we are still far from eliminating either the occurrence or longterm consequences of perinatal brain injury.

\section{Strategies to reduce long-term impact of perinatal brain injury Magnesium sulfate}

In the 1980s and 90s, researchers observed that rates of IVH and CP were lower among children whose mothers were exposed to magnesium sulfate [6-8]. In response to these observations, a number of retrospective studies exploring the association between magnesium and CP were published with mixed results [9-11]. Subsequently, five randomized controlled trials (RCTs) have been completed [12-16]. The largest trial included 2,241 mothers at risk for delivery between 24 and 31 weeks estimated gestational age (EGA) and demonstrated a relative risk (RR) of $\mathrm{CP}$ among magnesium sulfateexposed children of 0.55 (95\% confidence interval [CI] 0.32 to 0.95 ) compared to non-exposed children [16]. Several meta-analyses, including a Cochrane Review, of these studies have been completed [17-19]. Costantine and colleagues concluded that magnesium sulfate significantly reduced the risk of $\mathrm{CP}$ among children delivered less than 32 to 34 weeks EGA with an RR for moderate to severe CP of 0.60 (95\% CI 0.43 to 0.84 ) [17]. Conde-Agudelo and Romero similarly concluded a protective effect of magnesium sulfate with an RR for moderate to severe CP of 0.64 (95\% CI 0.44 to 0.92 ) for infants delivered less than 34 weeks EGA [18]. In a recently published Cochrane Review including the same five trials, Doyle and colleagues concluded that although there was no significant effect of magnesium sulfate on pediatric mortality, there were significant reductions in neurologic injury (RR $0.85,95 \%$ CI 0.74 to 0.98 ). They concluded that the number of women needed to be treated with magnesium sulfate to prevent one case of CP was 63 (95\% CI 43 to 155) [19]. In light of these studies, the American College of Obstetricians and Gynecologists (ACOG) and the Society for Maternal-Fetal Medicine support the short-term use of magnesium sulfate for perinatal neuroprotection in fetuses at risk of delivery less than 32 weeks EGA [20].
Magnesium sulfate must be used with caution and the use of protocols for administration is recommended. Prolonged use ( $>48$ hours) is contraindicated due to the risk of bone abnormalities and calcium, phosphorous, and magnesium derangements in mothers and infants [21-24]. These risks recently prompted the Food and Drug Administration to change its categorization of magnesium sulfate from Pregnancy Category " $\mathrm{A}$ " (adequate and well-controlled studies have failed to demonstrate a risk to the fetus in the first trimester of pregnancy and there is no evidence of risk in later trimesters) to Pregnancy Category " $\mathrm{D}$ " (there is positive evidence of human fetal risk based on adverse reaction data from investigational or marketing experience or studies in humans, but potential benefits may warrant use of the drug in pregnant women despite potential risks) [25]. Although term infants are also at risk for $\mathrm{CP}$, and there is a potential that magnesium sulfate is neuroprotective for high-risk term infants, no published evidence supports the use of magnesium sulfate to prevent $\mathrm{CP}$ among infants born at term.

\section{Therapeutic hypothermia}

Animal models and studies of adults undergoing cardiovascular procedures prompted investigators in the 2000 s to investigate the role of therapeutic hypothermia for newborns with perinatal asphyxia (hypoxic-ischemic encephalopathy, HIE). Therapeutic hypothermia is thought to protect neurons from secondary injury as brain metabolism returns to normal following an asphyxia event. A number of RCTs demonstrate reductions in death and/or disability associated with therapeutic hypothermia. Although these studies used varied protocols and investigated different outcomes, most demonstrated at least some benefit in certain populations treated with hypothermia [26-31]. One of the larger studies included 208 term infants with evidence of HIE, 102 of whom were treated with whole-body hypothermia and 106 of whom underwent usual care. The primary outcome of death or moderate to severe disability at 18 to 22 months of age occurred in $44 \%$ of children treated with hypothermia versus $62 \%$ of children in the control group (RR 0.72, 95\% CI 0.54 to 0.95) [27]. A recent systematic review of 11 RCTs including 1,500 neonates ( $\geq 36$ weeks EGA) showed therapeutic hypothermia significantly reduced mortality or major neurodevelopmental disability up to 18 months of age with an RR of 0.75 (95\% CI 0.68 to 0.83 ) [32]. In light of these studies, cooling is now recommended within 6 hours of birth for term or near-term neonates with symptoms of moderate to severe HIE. Therapeutic hypothermia requires considerable resources that are typically only available at tertiary care centers [33]. A broad community awareness of the symptoms of HIE and the importance of prompt 
initiation of therapy (which may require transfer to a tertiary care center) is particularly important for optimizing this strategy of perinatal neuroprotection.

\section{Strategies to prevent perinatal brain injury Delayed clamping of the umbilical cord}

The decision about the appropriate time to clamp the umbilical cord has been debated for centuries. It is agreed that volemic state of the neonate is partially dependent on when the umbilical cord is clamped [34]. Immediate cord clamping (ICC) has historically been advocated to facilitate rapid resuscitation for preterm infants [35], to facilitate collecting umbilical cord blood gases [36], and for reduction in maternal hemorrhage. However, there is an expanding body of literature supporting delayed clamping of the umbilical cord (DCC) to prevent perinatal brain injury (among other beneficial neonatal outcomes), especially among premature infants.

Hofmeyr and colleagues performed an RCT of 38 women with preterm labor and compared ICC to DCC in 1988. This study revealed a significant decrease in ultrasound evidence for IVH in preterm infants with DCC versus ICC (35\% versus $77 \%$ ) [37]. Posited mechanisms for decreased rates of IVH associated with DCC include reduced risk of hypoperfusion and improved oxygen delivery to the brain [38]. Additionally, avoidance of packed red blood cell transfusion may reduce the risk of a reperfusion event. Further, DCC ensures that adequate clotting factors are delivered to the infant [39]. Finally, umbilical cord stem cells appear to be neuroprotective and have reduced infarct volume of hypoxic ischemic strokes in animal models [40]. Since the 1980s, multiple RCTs have revealed the potential benefits of DCC, including a decrease in red blood transfusion [41-43], decreased fluid resuscitation, lower incidence of IVH $[37,44]$, and delayed onset of sepsis [44]. Other studies of DCC have identified the risks of volume overload, polycythemia $[45,46]$, hyperbilirubinemia $[47,48]$, and the need for readmission for phototherapy as reasons to perform ICC. However, a 2006 RCT of infants less than 32 weeks confirmed the benefits of DCC and showed no increased risk of hyperbilirubinemia or adverse events due to polycythemia [44]. Based on this body of literature, ACOG now recommends a delay $(>30$ seconds) for infants delivered less than 32 weeks EGA with a potential $50 \%$ reduction in rates of IVH [49]. A potential alternative option for DCC is umbilical cord "milking" or sweeping across the umbilical cord to push blood towards the fetus. Rabe and colleagues performed an RCT of 58 neonates delivered less than 34 weeks EGA comparing milking of the umbilical cord versus DCC. They concluded that milking the umbilical cord four times achieved similar amounts of placental-fetal blood transfusion as DCC [50]. Should future studies confirm efficacy of umbilical cord milking, this may replace DCC and assuage concerns over the 30-second delay in neonatal resuscitation that arises from DCC.

Data supporting the use of DCC for prevention of perinatal brain injury among infants born at term is lacking. Term infants are at lower risk for packed red blood cell transfusions, IVH, and late-onset sepsis, thus reductions in these outcomes have not been demonstrated. The main benefit conferred from DCC in term infants is increased iron stores at 4 to 6 months of life. Iron is utilized in brain development [51] and studies have demonstrated correlations between reduced iron stores and cognitive and behavioral deficits [52]. In a meta-analysis of 15 available trials on term neonates, Hutton and Hassan concluded that delaying clamping of the umbilical cord has beneficial effects on iron status. Although this meta-analysis did not address the issue specifically, improved iron stores may impact neurodevelopmental outcomes, particularly among children in developing countries and breastfed infants who are not supplemented with iron [53]. A recently published Cochrane review, which included 15 trials and a total of 3,911 term infants, revealed improvement in iron stores in infants who had DCC versus ICC [54]. The only published trial to formally study neurodevelopmental outcomes among children with DCC versus ICC did not show a difference [55]. At this time, the ideal timing of clamping of the umbilical cord in term infants to optimize neurological outcomes is not clear.

\section{Infections}

A considerable number of studies have supported the conclusion that maternal infections of any type, but particularly infection of the fetal membranes (chorioamnionitis), are associated with the development of CP in term and preterm infants [56-59]. The mechanisms of fetal brain injury due to infection are likely associated with elevated maternal temperature; release of cytokines, free radicals, and glutamate; and vascular injury associated with infection [60]. There is evidence that the fetal immune system and inflammatory responses in the fetus are drivers of brain injury when infections occur. The fetal inflammatory response syndrome (FIRS), described by Romero and colleagues, is characterized by changes in fetal hematologic profiles, including increased white blood cell and neutrophil counts [61].

The most commonly studied association is between chorioamnionitis and CP. In 2000, Wu and Colford performed a meta-analysis of 26 studies and demonstrated that clinical chorioamnionitis was associated 
with CP with an RR of 1.9 (95\% CI 1.4 to 2.5). Among only full-term infants, the RR was 4.7 (95\% CI 1.3 to 16.2) [62]. A meta-analysis by Shatrov and colleagues of 15 studies published since 2000 again demonstrated an association between clinical chorioamnionitis and CP with an odds ratio (OR) of 1.83 (95\% CI 1.17 to 2.89) [63]. Unfortunately, there does not appear to be a reduction in risk of $\mathrm{CP}$ with antibiotic administration or immediate delivery upon diagnosis of chorioamnionitis.

Other studies suggest that the association between maternal infection and $\mathrm{CP}$ is not limited to uterine infections. Ahlin and colleagues performed a case-control study of 309 term-delivered children with CP and showed an association between spastic hemiplegia-type CP and bacteruria (OR 4.7, 95\% CI 1.5 to 15.2 ), any infectious disease during pregnancy (OR 2.9, 95\% CI 1.7 to 4.8 ), severe infection during pregnancy (OR 15.4, 95\% CI 3.0 to 78.1), and antibiotic therapy during pregnancy (OR 6.3, $95 \%$ CI 3.0 to 15.2) [64]. Wu et al. performed a population-based study in Denmark including all firstbornsingletons born between January 1982 and December 2004 to investigate the association between CP (or epilepsy) and maternal infection either before or during pregnancy. The study included approximately 625,000 children and demonstrated that maternal infection of the genitourinary system during pregnancy was associated with an increased risk of CP (adjusted hazard ratio [aHR] $1.63,95 \%$ CI 1.34 to 1.98 ). A history of genitourinary infection prior to pregnancy was not associated with an increased risk of CP [65]. Finally, Streja and colleagues recently published a case-controlled study of more than 80,000 mothers and showed that self-reported vaginal infections (aHR 1.52, 95\% CI 1.04 to 2.24) and fever during pregnancy (aHR 1.53, 95\% CI 1.06 to 2.21 ) were associated with increased risk of CP [66].

The pathophysiologic mechanisms whereby maternal infection causes fetal brain injury have yet to be clearly elucidated, although the growing body of research on the fetal-maternal interface, FIRS, and the fetal immune system in general is likely to provide significant opportunities for intervention. Until strategies to protect the fetal brain from the impacts of maternal infection are available, perinatal neuroprotective strategies with regard to infection are limited. Treatment of maternal fever, augmentation of labor for patients at full term with premature rupture of membranes, and avoidance of excessive cervical examinations after ruptured membranes may be important strategies to prevent perinatal brain injury, but such data are lacking. In the future, a better understanding of the biochemical mechanisms of infection-related perinatal brain injury may improve options for perinatal neuroprotection in the setting of infection.

\section{Prevention of preterm birth}

Given the high association between perinatal brain injury and prematurity, any strategy that reduces preterm birth will also reduce the occurrence of perinatal brain injury. Unfortunately, the ability to predict or prevent preterm birth is extremely limited and the majority of preterm deliveries occur in women who were not identified prenatally to be high-risk. There has been recent improvement in preventing recurrent preterm birth and preterm birth in women with a prenatally diagnosed short cervix. Over the last 5 years, a number of wellconducted RCTs have demonstrated the benefit of progesterone supplementation for the prevention of preterm birth among certain high-risk women. Meis and colleagues at the National Institute of Child Health and Human Development showed that treatment of women with a history of prior preterm birth with 17 hydroxyprogesterone acetate (17P) reduced the risk of recurrent preterm birth at all gestational ages with an RR for delivery less than 32 weeks EGA of 0.58 (95\% CI 0.37 to 0.91 ) [67]. Romero and colleagues performed a metaanalysis including 5 trials and 775 women and investigated the role of vaginal progesterone in women with ultrasound evidence of decreased cervical length. The authors demonstrated a significant reduction in preterm birth at all gestational ages, with an RR of 0.5 (95\% CI 0.3 to 0.81 ) for delivery less than 28 weeks [68]. Currently, progesterone for at-risk women is the only available strategy to prevent perinatal brain injury by preventing preterm births. Unfortunately, techniques to stop or prevent spontaneous preterm labor are lacking and studies evaluating routine cervical length screening, uterine monitoring, and other techniques in low-risk women have been unsuccessful.

\section{Emerging strategies \\ Banked umbilical cord blood}

Human umbilical cord blood is rich in pluripotent cell types such as mesenchymal stem cells that have high regenerative potential in many types of tissues, including neuronal tissue. Banked umbilical cord blood has been used for decades as a source of stem cells to treat a variety of hematologic diseases such as inherited anemias or hematologic malignancies [69]. Several studies in rodent models suggest that stem cells derived from umbilical cord blood may have therapeutic potential for HIE. Studies by both Meier and colleagues [70] and Pimentel-Coelho and colleagues [71] demonstrate that intraperitoneal administration of human umbilical cord blood-derived stem cells resulted in alleviation of neurologic symptoms in neonatal rats following carotid artery ligation and exposure to low oxygen conditions shortly after birth (a model felt to appropriately replicate human perinatal asphyxia). Xia and colleagues performed 
intracerebral transplantation of mesenchymal stem cells from cord blood into rats exposed to HIE conditions and demonstrated improvement in neurological severity scores [72]. Although there is not yet evidence of benefit in humans and infusion of cord blood is not currently an available treatment modality for $\mathrm{HIE}$, experts on the topic have called for clinical trials [73] and according to the United States database of ongoing clinical trials (clinicaltrials.gov), there appear to be at least two ongoing studies [74].

\section{Erythropoietin}

Erythropoietin (Epo) is a hematopoietic cytokine that has been demonstrated to have neuroregenerative, angiogenic, and anti-inflammatory effects in the brain. This observation led to investigation of Epo as a potential agent for mitigating the effects of HIE. Several animal trials have demonstrated approximately $40 \%$ to $50 \%$ improvement in neuron counts in rodents exposed to HIE conditions followed by treatment with Epo [75-77]. A number of other rodent studies have demonstrated improved neurologic outcomes in HIE and neonatal stroke rodent models with Epo treatment [78-81]. These and other animal studies prompted human studies. A study by Zhu and colleagues included 167 term infants with moderate to severe HIE who were randomized to receive either Epo or supportive therapy (not including therapeutic hypothermia). In 18 months of follow-up, death or moderate/severe disability occurred in $43.8 \%$ of the control group and $24.6 \%$ of the Epo group ( $P=$ 0.017 ) [82]. Elmahdy et al. performed a prospective casecontrol study to examine biochemical and other changes associated with Epo therapy in HIE-affected neonates. The study included 15 normal healthy infants, 15 infants with mild to moderate HIE who were treated with Epo, and 15 infants with mild to moderate HIE who did not receive Epo. None of the HIE-affected infants were cooled. This study showed significant improvement in the electroencephalograms in the Epo-treated HIE-affected infants in addition to decreased nitric oxide concentrations at 2 weeks of life. At 6 months, Epo-treated infants had improved neurologic and developmental outcomes [83]. Given the considerable improvement in outcomes associated with neonatal hypothermia for HIE-affected neonates, Wu and colleagues performed a phase I study to investigate the use of Epo in conjunction with cooling. They demonstrated that in 24 infants with HIE, Epo administered to infants undergoing therapeutic hypothermia is well tolerated and produces plasma concentrations that are neuroprotective in animals [84]. At this time, there appear to be a number of ongoing larger human randomized trials investigating the long-term effects of Epo in conjunction with therapeutic hypothermia for treatment of HIE [74].

\section{Other investigational interventions}

In addition to cord blood and Epo, there are multiple agents that are currently under investigation in animal models to improve neurologic outcomes for HIE. Strategies to improve neuroregeneration, modify the immune response to hypoxia, and improve angiogenic responses to hypoxia are all areas of active investigation. Compounds that have demonstrated neuroprotective effects in animal models include uridine (the principal pyrimidine in humans and a membrane phospholipid precursor) [85], levetiracetam (which appears to reduce neuronal apoptosis) [86], microRNA-210-mimics (which likely play a role in cellular regulation in response to hypoxemia) [87], ethyl pyruvate (which has shown efficacy in other conditions, including hemorrhagic shock and sepsis) [88], melatonin (which has antiinflammatory, sedative, and protective effects against oxidative stress) [89], thyroxine (which is important for oligodendrocyte maturation and myelination) [90], and Shenfu, a traditional Chinese herb [91]. Studies investigating other agents are being published almost daily. These agents will need to be studied more broadly in animal models, and if they continue to demonstrate efficacy and safety in rodents, they will require testing in humans. Ultimately, it seems likely that in the future a "cocktail" of various agents will be utilized to treat infants with HIE that will act on the different pathways that lead to long-term injury.

\section{Future directions}

The strategies described here clearly have the potential to reduce the incidence and long-term consequences of perinatal brain injury. However, there are still high rates of morbidity and mortality associated with perinatal brain injury. Prediction and prevention of preterm birth are critical steps in reducing this outcome. Additionally, clinical tools to reliably predict term fetuses at risk for HIE and strategies to ameliorate that risk before brain injury occurs are imperative. Finally, a better understanding of the pathophysiologic mechanisms of brain injury due to various perinatal insults is necessary for development of tools to prevent the neural consequences of unavoidable injuries.

\section{Abbreviations}

17P, 17 hydroxyprogesterone acetate; ACOG, American College of Obstetricians and Gynecologists; aHR, adjusted hazard ratio; $\mathrm{CI}$, confidence interval; $\mathrm{CP}$, cerebral palsy; DCC, delayed cord clamping; EGA, estimated gestational age; Epo, erythropoietin; FIRS, fetal inflammatory response syndrome; HIE, hypoxic-ischemic encephalopathy; ICC, immediate cord clamping; IVH, intraventricular hemorrhage; OR, odds ratio; RCT, randomized controlled trial; RR, relative risk. 


\section{Disclosures}

The authors declare that they have no competing interests.

\section{References}

I. Rosenbaum P, Paneth N, Leviton A, Goldstein M, Bax M, Damiano D, Dan $B$, Jacobsson $B$ : A report: the definition and classification of cerebral palsy April 2006. Dev Med Child Neurol Suppl 2007, 109:8-|4.

2. Winter S, Autry A, Boyle C, Yeargin-Allsopp M: Trends in the prevalence of cerebral palsy in a population-based study. Pediatrics 2002, I | 0: | 220-5.

\section{FlOOOPrime}

\section{RECOMMENDED}

3. Economic costs associated with mental retardation, cerebral palsy, hearing loss, and vision impairment-United States, 2003. MMWR Morb Mortal Wkly Rep 2004, 53:57-9.

4. Kruse M, Michelsen SI, Flachs EM, Brønnum-Hansen $H$, Madsen $M$, Uldall P: Lifetime costs of cerebral palsy. Dev Med Child Neurol 2009, 5 I:622-8.

5. Crowley PA: Antenatal corticosteroid therapy: a meta-analysis of the randomized trials, 1972 to 1994. Am J Obstet Gynecol I995, I 73:322-35.

6. van de Bor M, Verloove-Vanhorick SP, Brand R, Keirse MJ, Ruys JH: Incidence and prediction of periventricular-intraventricular hemorrhage in very preterm infants. J Perinat Med I987, I 5:333-9.

7. Leviton A, Kuban KC, Pagano M, Brown ER, Krishnamoorthy KS, Allred EN: Maternal toxemia and neonatal germinal matrix hemorrhage in intubated infants less than $1751 \mathrm{~g}$. Obstet Gynecol 1988, 72:57|-6.

8. Kuban KC, Leviton A, Pagano M, Fenton T, Strassfeld R, Wolff M: Maternal toxemia is associated with reduced incidence of germinal matrix hemorrhage in premature babies. J Child Neurol 1992, 7:70-6.

9. O'Shea TM, Klinepeter KL, Dillard RG: Prenatal events and the risk of cerebral palsy in very low birth weight infants. Am J Epidemiol 1998, |47:362-9.

10. Nelson KB, Grether JK: Can magnesium sulfate reduce the risk of cerebral palsy in very low birthweight infants? Pediatrics 1995, 95:263-9.

II. Wilson-Costello D, Borawski E, Friedman H, Redline R, Fanaroff AA Hack M: Perinatal correlates of cerebral palsy and other neurologic impairment among very low birth weight children. Pediatrics 1998, 102:315-22.

12. Mittendorf R, Dambrosia J, Pryde PG, Lee K, Gianopoulos JG, Besinger RE, Tomich PG: Association between the use of antenatal magnesium sulfate in preterm labor and adverse health outcomes in infants. Am J Obstet Gynecol 2002, I 86: I I I I-8.

13. Crowther CA, Hiller JE, Doyle LW, Haslam RR: Effect of magnesium sulfate given for neuroprotection before preterm birth: a randomized controlled trial. JAMA 2003, 290:2669-76.

\section{FlOOOPrime}

\section{RECOMMENDED}

14. The Magpie Trial: a randomised trial comparing magnesium sulphate with placebo for pre-eclampsia. Outcome for children at 18 months. BJOG 2007, I | 4:289-99.

15. Marret S, Marpeau L, Zupan-Simunek V, Eurin D, Lévêque C, Hellot M, Bénichou J: Magnesium sulphate given before verypreterm birth to protect infant brain: the randomised controlled PREMAG trial*. BJOG 2007, I |4:3 I0-8.

16. Rouse DJ, Hirtz DG, Thom E, Varner MW, Spong CY, Mercer BM, lams JD, Wapner RJ, Sorokin Y, Alexander JM, Harper M, Thorp JM, Ramin SM, Malone FD, Carpenter M, Miodovnik M, Moawad A O'Sullivan MJ, Peaceman AM, Hankins GDV, Langer O, Caritis SN, Roberts JM: A randomized, controlled trial of magnesium sulfate for the prevention of cerebral palsy. N Engl ] Med 2008 , 359:895-905

FlOOOPrime

17. Costantine MM, Weiner S): Effects of antenatal exposure to magnesium sulfate on neuroprotection and mortality in preterm infants: a meta-analysis. Obstet Gynecol 2009, I | 4:354-64.

\section{FlOOOPrime}

RECOMMENDED

18. Conde-Agudelo A, Romero R: Antenatal magnesium sulfate for the prevention of cerebral palsy in preterm infants less than 34 weeks' gestation: a systematic review and metaanalysis. Am J Obstet Gynecol 2009, 200:595-609.

\section{FlOOOPrime}

\section{RECOMMENDED}

19. Doyle LW, Crowther CA, Middleton P, Marret S, Rouse D Magnesium sulphate for women at risk of preterm birth for neuroprotection of the fetus. Cochrane Database Syst Rev 2009:CD00466I.

FlOOOPrime

20. Committee Opinion No. 573: Magnesium sulfate use in obstetrics. Obstet Gynecol 2013, I 22:727-8.

\section{FlOOPPrime}

\section{RECOMMENDED}

2I. Yokoyama K, Takahashi N, Yada Y, Koike Y, Kawamata R, Uehara R, Kono $Y$, Honma $Y$, Momoi MY: Prolonged maternal magnesium administration and bone metabolism in neonates. Early Hum Dev 20|0, 86:|87-9|

FlOOOPrime

22. Wedig KE, Kogan J, Schorry EK, Whitsett JA: Skeletal deminer alization and fractures caused by fetal magnesium toxicity. J Perinatol 2006, 26:37I-4.

23. Malaeb SN, Rassi Al, Haddad MC, Seoud MA, Yunis KA: Bone mineralization in newborns whose mothers received magnesium sulphate for tocolysis of premature labour. Pediatr Radiol 2004, 34:384-6.

24. Nassar AH, Sakhel K, Maarouf H, Naassan GR, Usta IM: Adverse maternal and neonatal outcome of prolonged course of magnesium sulfate tocolysis. Acta Obstet Gynecol Scand 2006 , 85: $1099-103$

\section{FlOOPrime}

\section{RECOMMENDED}

25. FDA Drug Safety Communications: FDA Recommends against prolonged use of magnesium sulfate to stop preterm labor due to bone changes in exposed babies. [http://www.fda.gov/ Drugs/DrugSafety/ucm353333.htm].

26. Gluckman PD, Wyatt JS, Azzopardi D, Ballard R, Edwards AD Ferriero DM, Polin RA, Robertson CM, Thoresen M, Whitelaw A Gunn AJ: Selective head cooling with mild systemic hypothermia after neonatal encephalopathy: multicentre randomised trial. Lancet 2005, 365:663-70.

\section{FIOOOPRime
RECOMMENDED}

27. Shankaran S, Laptook AR, Ehrenkranz RA, Tyson JE, McDonald SA, Donovan EF, Fanaroff AA, Poole WK, Wright LL, Higgins RD, Finer NN Carlo WA, Duara S, Oh W, Cotten CM, Stevenson DK, Stoll BJ, Lemons JA, Guillet R, Jobe $A H$ : Whole-body hypothermia for neonates with hypoxic-ischemic encephalopathy. $N$ Engl J Med 2005, 353:1574-84.

\section{FIOOOPrime}

28. Azzopardi DV, Strohm B, Edwards AD, Dyet L, Halliday HL, Juszczak E, Kapellou O, Levene M, Marlow N, Porter E, Thoresen M, Whitelaw A, 
Brocklehurst P: Moderate hypothermia to treat perinatal asphyxial encephalopathy. N Engl J Med 2009, 36 I:1349-58.

\section{FIOOOPrime}

29. Simbruner G, Mittal RA, Rohlmann F, Muche R: Systemic hypothermia after neonatal encephalopathy: outcomes of neo.nEURO.network RCT. Pediatrics 2010, I26:e77|-8.

30. Zhou W, Cheng G, Shao X, Liu X, Shan R, Zhuang D, Zhou C, Du L, Cao Y, Yang Q, Wang L: Selective head cooling with mild systemic hypothermia after neonatal hypoxic-ischemic encephalopathy: a multicenter randomized controlled trial in China. J Pediatr 2010, 157:367-72, 372.el-3.

31. Jacobs SE, Morley CJ, Inder TE, Stewart MJ, Smith KR, McNamara PJ, Wright IMR, Kirpalani HM, Darlow BA, Doyle LW: Whole-body hypothermia for term and near-term newborns with hypoxicischemic encephalopathy: a randomized controlled trial. Arch Pediatr Adolesc Med 20 I I, 165:692-700.

FlOOOPrime RECOMMENDED

32. Jacobs SE, Berg M, Hunt R, Tarnow-Mordi WO, Inder TE, Davis PG: Cooling for newborns with hypoxic ischaemic encephalopathy. Cochrane Database Syst Rev 2013, I:CD0033II.

\section{FlOOOPrime}

\section{RECOMMENDED}

33. Barks JDE: Technical aspects of starting a neonatal cooling program. Clin Perinatol 2008, 35:765-75, vii.

34. Yao AC, Lind J: Blood flow in the umbilical vessels during the third stage of labor. Biol Neonate 1974, 25:186-93.

35. McCausland AM, Holmes F, Schumann WR: Management of cord and placental blood and its effect upon the newborn. Part II. West J Surg Obstet Gynecol 1950, 58:591-608.

36. Utility of umbilical cord blood acid-base assessment. ACOG Committee Opinion: Committee on Obstetric Practice. Number 138-April 1994. Int J Gynaecol Obstet 1994, 45:303-4.

37. Hofmeyr GJ, Bolton KD, Bowen DC, Govan JJ: Periventricularl intraventricular haemorrhage and umbilical cord clamping. Findings and hypothesis. S Afr Med J 1988, 73:104-6.

\section{FlOOOPrime} RECOMMENDED

38. Baenziger O, Stolkin F, Keel M, Siebenthal $K$ von, Fauchere J, Das Kundu S, Dietz V, Bucher $\mathrm{H}$, Wolf M: The influence of the timing of cord clamping on postnatal cerebral oxygenation in preterm neonates: a randomized, controlled trial. Pediatrics 2007, I 19:455-9.

39. Bonnar J, McNicol GP, Douglas AS: The blood coagulation and fibrinolytic systems in the newborn and the mother at birth. J Obstet Gynaecol Br Commonw 197I, 78:355-60.

40. Park $D$, Borlongan $C V$, Willing $A E$, Eve $D J$, Cruz LE, Sanberg $C D$, Chung Y, Sanberg PR: Human umbilical cord blood cell grafts for brain ischemia. Cell Transplant 2009, 18:985-98.

4I. Rabe H, Wacker A, Hülskamp G, Hörnig-Franz I, Schulze-Everding A, Harms E, Cirkel U, Louwen F, Witteler R, Schneider HP: A randomised controlled trial of delayed cord clamping in very low birth weight preterm infants. EurJ Pediatr 2000, 159:775-7.

\section{FlOOOPrime}

42. McDonnell M, Henderson-Smart DJ: Delayed umbilical cord clamping in preterm infants: a feasibility study. J Paediatr Child Health 1997, 33:308-10.

\section{FlOOOPrime}

43. Kinmond S, Aitchison TC, Holland BM, Jones JG, Turner TL, Wardrop CA: Umbilical cord clamping and preterm infants: a randomised trial. BMJ 1993, 306: $172-5$.
44. Mercer JS, Vohr BR, McGrath MM, Padbury JF, Wallach M, Oh W: Delayed cord clamping in very preterm infants reduces the incidence of intraventricular hemorrhage and late-onset sepsis: a randomized, controlled trial. Pediatrics 2006, I I 7: |235-42.

\section{FlOOOPrime
RECOMMENDED}

45. Saigal S, Usher RH: Symptomatic neonatal plethora. Biol Neonate 1977, 32:62-72.

46. Oh W: Neonatal polycythemia and hyperviscosity. Pediatr Clin North Am 1986, 33:523-32.

47. van Rheenen $\mathrm{P}, \mathrm{Brabin} \mathrm{BJ}$ : Late umbilical cord-clamping as an intervention for reducing iron deficiency anaemia in term infants in developing and industrialised countries: a systematic review. Ann Trop Paediatr 2004, 24:3-16.

48. Saigal S, O'Neill A, Surainder Y, Chua LB, Usher R: Placental transfusion and hyperbilirubinemia in the premature. Pediatrics 1972, 49:406-19.

49. Committee Opinion No.543: Timing of umbilical cord clamping after birth. Obstet Gynecol 2012, I 20:1522-6.

50. Rabe H, Jewison A, Alvarez RF, Crook D, Stilton D, Bradley R, Holden D: Milking compared with delayed cord clamping to increase placental transfusion in preterm neonates: a randomized controlled trial. Obstet Gynecol 201 I, I I7:205-II.

\section{FlOOOPrime
RECOMMENDED}

5I. Carlson ES, Tkac I, Magid R, O'Connor MB, Andrews NC, Schallert T, Gunshin H, Georgieff MK, Petryk A: Iron is essential for neuron development and memory function in mouse hippocampus. J Nutr 2009, 139:672-9.

52. Lozoff B, Brittenham GM, Wolf AW, McClish DK, Kuhnert PM, Jimenez E, Jimenez R, Mora LA, Gomez I, Krauskoph D: Iron deficiency anemia and iron therapy effects on infant developmental test performance. Pediatrics 1987, 79:981-95.

53. Hutton EK, Hassan ES: Late vs early clamping of the umbilical cord in full-term neonates: systematic review and metaanalysis of controlled trials. JAMA 2007, 297:1241-52.

\section{FIOOOPrime}

54. McDonald SJ, Middleton P, Dowswell T, Morris PS: Effect of timing of umbilical cord clamping of term infants on maternal and neonatal outcomes. Cochrane Database Syst Rev 2013, 7:CD004074.

\section{FlOOOPrime
RECOMMENDED}

55. Andersson O, Domellöf M, Andersson D, Hellström-Westas L: Effects of delayed cord clamping on neurodevelopment and infection at four months of age: a randomised trial. Acto Paediatr 2013, 102:525-31.

56. Eastman NJ, Deleon M: The etiology of cerebral palsy. Am J Obstet Gynecol 1955, 69:950-6I.

57. Grether JK, Nelson KB: Maternal infection and cerebral palsy in infants of normal birth weight. JAMA 1997, 278:207-II.

58. Leviton A, Paneth N, Reuss ML, Susser M, Allred EN, Dammann O, Kuban K, van Marter LJ, Pagano M, Hegyi T, Hiatt M, Sanocka U, Shahrivar F, Abiri M, Disalvo D, Doubilet P, Kairam R, Kazam E, Kirpekar M, Rosenfeld D, Schonfeld S, Share J, Collins M, Genest D, ShenSchwarz S: Maternal infection, fetal inflammatory response, and brain damage in very low birth weight infants. Developmental Epidemiology Network Investigators. Pediatr Res 1999, 46:566-75.

59. Elovitz MA, Brown AG, Breen K, Anton L, Maubert M, Burd I: Intrauterine inflammation, insufficient to induce parturition, still evokes fetal and neonatal brain injury. Int J Dev Neurosci 2011, 29:663-7I.

60. Kasdorf E, Perlman JM: Hyperthermia, inflammation, and perinatal brain injury. Pediatr Neurol 2013, 49:8-14.

6I. Romero R, Savasan ZA, Chaiworapongsa T, Berry SM, Kusanovic JP, Hassan SS, Yoon BH, Edwin S, Mazor M: Hematologic profile of 
the fetus with systemic inflammatory response syndrome. J Perinat Med 201I, 40:19-32.

62. $\mathrm{Wu}$ YW, Colford JM: Chorioamnionitis as a risk factor for cerebral palsy: A meta-analysis. JAMA 2000, 284:1417-24.

\section{FlOOOPrime} RECOMMENDED

63. Shatrov JG, Birch SCM, Lam LT, Quinlivan JA, Mclntyre S, Mendz GL: Chorioamnionitis and cerebral palsy: a meta-analysis. Obstet Gynecol 2010, I1 6:387-92.

\section{FlOOOPrime}

\section{RECOMMENDED}

64. Ahlin K, Himmelmann K, Hagberg G, Kacerovsky M, Cobo T, Wennerholm $U$, Jacobsson $B$ : Cerebral palsy and perinatal infection in children born at term. Obstet Gynecol 20I3, I 22:4 I-9.

65. Wu CS, Pedersen LH, Miller JE, Sun Y, Streja E, Uldall P, Olsen J: Risk of cerebral palsy and childhood epilepsy related to infections before or during pregnancy. PLOS ONE 2013, 8:e57552.

66. Streja E, Miller JE, Bech BH, Greene N, Pedersen LH, YearginAllsopp M, van Naarden Braun K, Schendel DE, Christensen D, Uldall $P$, Olsen J: Congenital cerebral palsy and prenatal exposure to self-reported maternal infections, fever, or smoking. Am J Obstet Gynecol 2013, 209:332.el-332.el0.

67. Meis PJ, Klebanoff M, Thom E, Dombrowski MP, Sibai B, Moawad AH, Spong CY, Hauth JC, Miodovnik M, Varner MW, Leveno KJ, Caritis SN, lams JD, Wapner RJ, Conway D, O'Sullivan MJ, Carpenter M, Mercer B, Ramin SM, Thorp JM, Peaceman AM, Gabbe S: Prevention of recurrent preterm delivery by 17 alpha-hydroxyprogesterone caproate. N Engl 」 Med 2003, 348:2379-85.

\section{FlOOOPrime \\ RECOMMENDED}

68. Romero R, Nicolaides K, Conde-Agudelo A, Tabor A, O'Brien JM, Cetingoz E, Da Fonseca E, Creasy GW, Klein K, Rode L, Soma-Pillay P, Fusey S, Cam C, Alfirevic Z, Hassan SS: Vaginal progesterone in women with an asymptomatic sonographic short cervix in the midtrimester decreases preterm delivery and neonatal morbidity: a systematic review and metaanalysis of individual patient data. Am J Obstet Gynecol 20I2, 206:I24.el-19.

\section{FlOOOPrime}

\section{RECOMMENDED}

69. Gluckman E: Milestones in umbilical cord blood transplantation. Blood Rev 201 I, 25:255-9.

70. Meier C, Middelanis J, Wasielewski B, Neuhoff S, Roth-Haerer A, Gantert M, Dinse HR, Dermietzel R, Jensen A: Spastic paresis after perinatal brain damage in rats is reduced by human cord blood mononuclear cells. Pediatr Res 2006, 59:244-9.

\section{FlOOOPrime}

\section{RECOMMENDED}

71. Pimentel-Coelho PM, Magalhães ES, Lopes LM, de Azevedo LC, Santiago MF, Mendez-Otero R: Human cord blood transplantation in a neonatal rat model of hypoxic-ischemic brain damage: functional outcome related to neuroprotection in the striatum. Stem Cells Dev 2010, 19:35I-8.

\section{FlOOOPrime}

72. Xia G, Hong X, Chen X, Lan F, Zhang G, Liao L: Intracerebral transplantation of mesenchymal stem cells derived from human umbilical cord blood alleviates hypoxic ischemic brain injury in rat neonates. J Perinat Med 2010, 38:215-21.

73. Carroll J: Human cord blood for the hypoxic-ischemic neonate. Pediatr. Res 2012, 71:459-63.

74. Clinical Trials Database. [http://clinicaltrials.gov/ct2/results?term= umbilical+cord+blood+and+neonatal+brain+injury\&Search=Search].

75. Aydin A, Genç K, Akhisaroglu M, Yorukoglu K, Gokmen N, Gonullu E: Erythropoietin exerts neuroprotective effect in neonatal rat model of hypoxic-ischemic brain injury. Brain Dev 2003, 25:494-8.

76. Matsushita H, Johnston MV, Lange MS, Wilson MA: Protective effect of erythropoietin in neonatal hypoxic ischemia in mice. Neuroreport 2003, 14:|757-6|.

77. Kumral A, Ozer E, Yilmaz O, Akhisaroglu M, Gokmen N, Duman N, Ulukus C, Genc S, Ozkan H: Neuroprotective effect of erythropoietin on hypoxic-ischemic brain injury in neonatal rats. Biol Neonate 2003, 83:224-8.

78. Chang YS, Mu D, Wendland M, Sheldon RA, Vexler ZS, McQuillen PS, Ferriero DM: Erythropoietin improves functional and histological outcome in neonatal stroke. Pediatr Res 2005, 58:106-II.

79. Gonzalez FF, Abel R, Almli CR, Mu D, Wendland M, Ferriero DM: Erythropoietin sustains cognitive function and brain volume after neonatal stroke. Dev Neurosci 2009, 3 I:403-I I.

80. Iwai M, Stetler RA, Xing J, Hu X, Gao Y, Zhang W, Chen J, Cao G: Enhanced oligodendrogenesis and recovery of neurological function by erythropoietin after neonatal hypoxic/ischemic brain injury. Stroke 2010, 4I:1032-7.

8I. Kumral A, Uysal N, Tugyan K, Sonmez A, Yilmaz O, Gokmen N, Kiray M, Genc S, Duman N, Koroglu TF, Ozkan H, Genc K: Erythropoietin improves long-term spatial memory deficits and brain injury following neonatal hypoxia-ischemia in rats. Behav Brain Res 2004, 153:77-86.

82. Zhu C, Kang W, Xu F, Cheng X, Zhang Z, Jia L, Ji L, Guo X, Xiong H, Simbruner G, Blomgren K, Wang X: Erythropoietin improved neurologic outcomes in newborns with hypoxic-ischemic encephalopathy. Pediatrics 2009, I 24:e2 |8-26.

\section{FIOOOPrime
RECOMMENDED}

83. Elmahdy H, El-Mashad A, El-Bahrawy H, El-Gohary T, El-Barbary A, Aly $\mathrm{H}$ : Human recombinant erythropoietin in asphyxia neonatorum: pilot trial. Pediatrics 2010, I25:el I35-42.

\section{FlOOOPrime RECOMMENDED}

84. Wu YW, Bauer LA, Ballard RA, Ferriero DM, Glidden DV, Mayock DE, Chang T, Durand DJ, Song D, Bonifacio SL, Gonzalez FF, Glass HC, Juul SE: Erythropoietin for neuroprotection in neonatal encephalopathy: safety and pharmacokinetics. Pediatrics 2012, I30:683-91.

\section{FlOOOPrime
RECOMMENDED}

85. Cansev M, Minbay Z, Goren B, Yaylagul EO, Cetinkaya M, Koksal N, Alkan $T$ : Neuroprotective effects of uridine in a rat model of neonatal hypoxic-ischemic encephalopathy. Neurosci Lett 2013, 542:65-70.

86. Kilicdag H, Daglıoglu K, Erdogan S, Guzel A, Sencar L, Polat S, Zorludemir S: The effect of levetiracetam on neuronal apoptosis in neonatal rat model of hypoxic ischemic brain injury. Early Hum Dev 2013, 89:355-60.

87. Qiu J, Zhou X, Zhou X, Cheng R, Liu H, Li Y: Neuroprotective Effects of MicroRNA-210 on Hypoxic-Ischemic Encephalopathy. Biomed Res Int 2013, 2013:350419.

88. Wang Y, Li B, Li Z, Huang S, Wang J, Sun R: Improvement of hypoxia-ischemia-induced white matter injury in immature rat brain by ethyl pyruvate. Neurochem Res 2013, 38:742-52.

89. Wang Z, Liu D, Zhan J, Xie K, Wang X, Xian X, Gu J, Chen W, Hao A: Melatonin improves short and long-term neurobehavioral deficits and attenuates hippocampal impairments after hypoxia in neonatal mice. Pharmacol Res 2013, 76:84-97.

90. Hung P, Huang C, Huang H, Tu D, Chang Y: Thyroxin treatment protects against white matter injury in the immature brain via brain-derived neurotrophic factor. Stroke 2013, 44:2275-83.

91. Yang L, Wang J, Tian Z, Yuan Y: Shenfu injection attenuates neonatal hypoxic-ischemic brain damage in rat. Neurol Sci 2013 , 34: $157 \mid-4$. 